\title{
Plasma Urotensin II concentration in gestational diabetes
}

\author{
Gestasyonel diyabette plazma Ürotensin II konsantrasyonu
}

\author{
Mehmet Hursitoglu ${ }^{1}$, Ali Ekiz ${ }^{2}$, Fatih Mete ${ }^{3}$, Yildiz Okuturlar ${ }^{1}$, Hakan Kocoglu ${ }^{1}$, Mustafa Cakirca ${ }^{5}$, Guleren \\ Dumanli $^{4}$, Gulden Anataca ${ }^{6}$, Oguzhan Kuru ${ }^{2}$, Serkan Dogan ${ }^{7}$, Bahar Pehlivan Ozdemir ${ }^{1}$, Omur Tabak ${ }^{4}$, \\ Gokhan Yildirim ${ }^{2}$, Hakan Dogan ${ }^{8}$, Betul Erismis ${ }^{1}$
}

\begin{abstract}
Aim: Urotensin II (UII) and its system is implicated in the etiology of many diseases (including diabetes mellitus). We tried in this study to evaluate and compare UII levels in gestational diabetes mellitus (GDM).

Methods: Thirty-six pregnant women (15 non-GDM patients consisted group 1 and 21 GDM patients consisted group 2) enrolled in this study. The 3rd group consisted of age matched 22 non pregnant healthy women. Plasma UII levels were determined at the beginning of the study. After 12 weeks of delivery, a second plasma UII was determined from group 1 and 2.

Results: Gestational UII levels of both GDM and non-GDM patients were higher than non-pregnant healthy controls ( $\mathrm{p}=0.0001$ for both). Both gestational and postpartum UII levels of GDM patients were higher than non-GDM patients but had not reached statistical significance $(\mathrm{P} \geq 0.05)$. Plasma UII concentrations in non-GDM patients significantly decreased after delivery but not in GDM patients $(p=0.036$ and $p \geq 0.05$, respectively)

Conclusions: The finding of elevated gestational plasma UII concentrations in GDM patients which did not decrease significantly after delivery (in compare to non-GDM patients) shows that plasma UII levels may have a role in the pathogenesis of GDM. Further detailed studies are needed in this field.

Keywords: Urotensin, gestational diabetes, pregnancy, glucose tolerance test
\end{abstract}

Öz

Amaç: Urotensin II (UII) ve sistemi, birçok hastalığın (diyabet dahil) etyolojisinde rol oynar. Bu çalışmada gestasyonel diabetes mellitusta (GDM) UII'yi değerlendirmek ve karşılaştırmayı denedik.

Yöntem: Çalışmaya alınan otuzaltı gebe (GDM olmayan 15 kadın hasta 1. Grubu ve 21 GDM kadın hasta 2. Grubu oluşturdu). Üçüncü grup, yaşları eşleştirilmiş 22 gebe olmayan sağlıklı bireyden oluşuyordu. Plazma UII seviyeleri çalışmanın başında belirlendi. Doğum sonrası 12.hafta ikinci bir plazma UII düzeyi grup 1 ve 2 'deki hastalardan ölçüldü.

Bulgular: Hem GDM hem de GDM olmayan deneklerin Gestasyonel UII düzeyleri, gebe olmayan sağlıklı kontrollere göre daha yüksekti (her ikisi için p=0,0001). GDM'li hastaların gestasyonel ve postpartum UII düzeyleri, GDM'li olmayan gebelere göre daha yüksekti ancak istatistiksel olarak anlamlı değildi $(\mathrm{p} \geq 0.05)$. GDM'li olmayan kişilerde plazma UII konsantrasyonları, doğumdan sonra anlamlı olarak azaldı, ancak GDM'li kişilerde değişmedi (sırasıyla, $p=0,036$ ve $p \geq 0.05$ ).

Sonuç: GDM hastalarında doğumdan sonra anlamlı bir şekilde azalmayan plazma UII konsantrasyonlarının yüksek bulunması (GDM olmayan bireylerle karşılaştırıldığında), UII'nin ve sisteminin GDM patogenezinde rol oynayabileceğini göstermektedir. $\mathrm{Bu}$ alanda daha ayrıntılı çalışmalara ihtiyaç vardır.

Anahtar kelimeler: Ürotensin, gestasyonel diyabet, gebelik, glukoz tolerans testi
${ }^{1}$ Department of Internal Medicine, Bakirkoy Dr.Sadi Konuk Education and Research Hospital, Istanbul, Turkey.

Bakırköy Dr. Sadi Konuk Ĕgitim ve Araștırma Hastanesi, İç Hastalıkları Kliniği, İstanbul, Türkiye.

2 Department of Obstetrics and Gynecology, Kanuni

Sultan Suleyman Education and Research Hospital, Istanbul, Turkey.

Kanuni Sultan Süleyman Eğitim ve Araştırma Hastanesi, Kadın Hastalıkları ve Doğum Kliniği, İstanbul, Türkiye.

${ }^{3}$ Department of Pediatrics, Kanuni Sultan Suleyman Education and Research Hospital, Istanbul, Turkey.

Kanuni Sultan Süleyman Eğitim ve Araștırma Hastanesi, Cocuk Hastalıkları Kliniği, İstanbul, Türkiye.

4 Department of Internal Medicine, Kanuni Sultan Suleyman Education and Research Hospital, Istanbul, Turkey.

Kanuni Sultan Süleyman Eğitim ve Araştırma Hastanesi, İç Hastalıkları Kliniği, İstanbul, Türkiye

Department of Internal Medicine, Bezmialem

University Medical Faculty, Istanbul, Turkey.

Bezmialem Vakıf Üniversitesi, Tip Fakültesi, İc Hastalıkları Anabilim Dalı İstanbul, Türkiye.

${ }^{6}$ Nurse of Diabetology, Kanuni Sultan Suleyman Education and Research Hospital, Istanbul, Turkey.

Diabet Hemşiresi, Kanuni Sultan Süleyman Eğitim ve

Araştırma Hastanesi, İstanbul, Türkiye.

${ }^{7}$ Ahenk Laboratory, Istanbul, Turkey.

Ahenk Laboratuarı, İstanbul, Türkiye.

${ }^{8}$ Izmir Bozyaka Training and Research Hospital, Department of Internal Medicine, Izmir, Turkey.

İzmir Bozyaka Eğitim ve Araştırma Hastanesi, İç Hastalıkları Kliniği, İstanbul, Türkiye.

Ethical approval: The study was approved by the local ethical committee.

Etik Kurul: Calıșmanın etik kurul onayı alınmıștır.

Conflict of Interest: No conflict of interest was declared by the authors.

Çıkar Çatışması: Yazarlar herhangi bir çıkar çatışması bildirmemişlerdir.

Financial Disclosure: The authors declared that this case has received no financial support.

Finansal Destek: Yazarlar bu olgu için finansal destek almadıklarını beyan etmişlerdir.

Geliș Tarihi / Received 05.09.2017

Kabul Tarihi / Accepted

07.11.2017

Yayın Tarihi/Published

01.12.2017

Sorumlu yazar / Corresponding author

Hakan Kocoglu

Adres-Address: Department of Internal Medicine, Bakirkoy Dr.Sadi Konuk Education and Research Hospital,

Istanbul,Turkey.

Tel: +90506 3809215

E-posta: dr.hakankocoglu@gmail.com

(C) Copyright 2017 ACEM 


\section{Introduction}

Urotensin II (UT) is the most potent endogenous vasoconstrictor peptide identified to date and its urotensin II receptor (UTR) are involved in the etiology of essential hypertension. This UT/UTR system, by accelerating the development of atherosclerosis, is also shared in the etiology of coronary artery disease [1,2]. It has been implicated in the pathophysiology of diabetes and metabolic syndrome by contributing to hyperglycemia, insulin resistance, and essential hypertension [3, 4]. It has got profibrotic effects in the heart [5].UT and UTR expression were found to be significantly increased in the myocardium of rats with diabetes (in comparison with healthy controls) which suggests a possible role of UT/UTR system in the pathophysiology of diabetic cardiomyopathy [2]. In spite of induced hyperglycemia, exogenous and endogenous UT displayed an inhibiting action on pancreatic beta-cell insulin secretion [6].

Gestational diabetes (GDM) and glucose intolerance that is first recognized during pregnancy is associated with various maternal and perinatal adverse outcomes. The mothers and their babies have increased risk of metabolic syndrome and diabetes mellitus [7]. The exact cause or mechanism of GDM is unknown but multiple factors, such as elevated human placental lactogen (hPL) or tumor necrosis factor- $\alpha$ (TNF- $\alpha$ ) levels and decreased adiponectin levels during pregnancy, are implicated in its etiology [8]. Tan et al.[9] noted a role of UII gene in susceptibility to GDM, i.e. G allele of site rs228648 increases and homozygous of this site decreases the susceptibility to GDM. As far as we know, there is no study evaluating serum UII levels in GDM patients. So in this study, we tried to compare plasma UII levels in GDM and non-GDM patients and healthy controls.

\section{Materials and Methods}

The protocol of this prospective study is approved by our hospital's ethics committee. A written consent was obtained from all the participants. In a period of one month, a total of 450 pregnant women who referred to our laboratory for oral glucose tolerance test (OGTT) were invited to participate in this study. Thirty-six of them who accepted this invitation were divided into 2 groups (according to $100 \mathrm{gr}$ glucose loading test results); group $1(n=15)$ consisted of non-GDM patients and group $2(n=21)$ consisted of GDM patients. Also, Group 1 patients were renamed as follows: pregnant non-GDM patients were named as Group 1A; post-partum non-GDM patients were named as Group 1B; and Group 2 patients were renamed as follows: pregnant GDM patients were named as Group 2A; post-partum GDM patients were named as Group 2B. The 3rd group consisted of age matched 22 non-pregnant healthy subjects. We used two step approach in pregnant women. GDM was diagnosed at 24-28 weeks of gestation with 100-gram three-hour oral glucose tolerance test (OGTT). The diagnostic criterion of the International Association of Diabetic Pregnancy Study Group (IADPSG) of GDM was used [10]. Exclusion criteria for all groups were as follows: 1-Inability to give a written consent, 2 Age less than 18 years, 3- Presence of hypo or hyperthyroidism, renal dysfunction, hypertension, ischemic heart disease, or malignancy, 4- presence of chronic infections or inflammatory status.

Behind routine biochemical parameters, blood samples for urotensin II level were taken from all participants at the start of the study. Another blood sample for urotensin II determination was taken from group 1 and 2 participants 12 weeks after delivery.

Routine laboratory tests were performed in our hospital's laboratory and plasma UII level was determined in
Ahenk Laboratory (Istanbul, Turkey). The details of blood sample collection for UII and its determination were discussed elsewhere [11].

The homeostasis model assessment-insulin resistance (HOMA-IR) index was calculated by the following formula: [fasting insulin $(\mathrm{uIU} / \mathrm{ml}) \times$ fasting blood glucose $(\mathrm{mmol} / \mathrm{L})] / 22.5$. Statistical analysis

Statistical analyses were performed using SPSS 22.0 statistical package for Windows. Data were expressed by descriptive statistics (mean, standard deviation, median and interquartile range). The distribution of variables was checked with the Kolmogorov-Smirnov test. For a comparison of variables of normal distribution, the t-test for independent samples was used and Mann-Whitney $U$ test was used for the comparison of variables with non-normal distribution. Pearson and its nonparametric equivalent (Spearman) tests were also used for evaluation of the correlation between quantitative variables. A value of $\mathrm{p}<0.05$ was accepted as statistically significant.

\section{Results}

There was no significant difference in mean age between the groups $(\mathrm{p} \geq 0.05)$. Fasting glucose levels of group 2 were significantly higher than group 1 and 3 (p was 0.001 , and 0.01 , respectively). Although fasting glucose levels in group 1 were higher than that of group 3, it had not reached statistically significance $(\mathrm{p} \geq 0.05)$ (Table 1$)$.

Comparing plasma UII concentrations of the groups showed that gestational UII levels of both GDM (group 2A) and non-GDM patients (Group 1A) were higher than non-pregnant healthy controls (Group 3) ( $\mathrm{p}=0.0001$ for both). Also gestational UII levels of GDM patients (Group 2A) were higher than nonGDM patients (Group 1A) but had not reached statistical significance but was close to it $(p=0.062)$. After delivery, difference in UII levels between the groups was same as above ( $\mathrm{p}=0.004, \mathrm{p}=0.019$ and $\mathrm{p}=0.217$, respectively). Comparing pregnancy and postpartum (PP) plasma UII levels showed a decrease in both GDM and non-GDM patients but it was significant only in non-GDM patients $(\mathrm{p}=0.036)$ (Table 1).

Comparison of gestational and postpartum laboratory parameters of pregnant women is shown in Table 2. Gestational blood glucose levels were higher in GDM (Group 2A) than nonGDM patients (Group 1A) but had not reached statistical significance but was close to it $(\mathrm{p}=0.053)$. In postpartum period, this difference was more prominent $(\mathrm{p}=0.005)$. Another point to mention is that $\mathrm{HbA} 1 \mathrm{c} \%$ levels were significantly different within and between the groups $(p=0.0001, p=0.004, p=0.0001$ and $\mathrm{p}=0.013$, respectively).

Mean plasma glucose levels of gestational 100 gram OGTT and postpartum 75 gram OGTT test results were different between non-GDM and GDM patients. Additionally, none of them remained diabetic after delivery (see figure 1 and 2 respectively for mean levels and their $\mathrm{p}$ values as well).

There was no significant correlation between gestational and postpartum UII levels and age or other study parameters of the participants.

\section{Discussion}

The vasoactive peptide UII has been shown to be increased in several disease conditions as hypertension, heart failure, atherosclerosis, kidney failure, etc. Surprisingly, its plasma levels were found to be higher in patents underwent kidney transplant than chronic renal failure and healthy control subjects [11]. In addition to its vasoactive effect, it also has a diabetogenic effect $[3,4]$. This may be partially due to its effect on insulin secretion from pancreatic cells. 
Table 1: Age and laboratory measures of the study groups.

\begin{tabular}{|c|c|c|c|c|c|c|c|c|c|c|}
\hline \multirow{4}{*}{$\mathrm{n}=58$} & \multicolumn{2}{|c|}{ Group 1A } & \multicolumn{2}{|c|}{ Group 2A } & \multicolumn{2}{|c|}{ Group 3} & \multirow{4}{*}{$\mathrm{p}$ value } & \multirow{2}{*}{$\begin{array}{r}\text { Group } \\
1 \mathrm{~A} \text { vs } 2 \mathrm{~A}\end{array}$} & \multirow{2}{*}{$\frac{\text { Group }}{2 \mathrm{~A} \text { vs } 3}$} & \multirow{2}{*}{$\frac{\text { Group }}{1 \mathrm{~A} \text { vs } 3}$} \\
\hline & Non-GD & $I(n=15)$ & GDM & $\mathrm{n}=21)$ & Healthy co & rols $(n=22)$ & & & & \\
\hline & \multirow{2}{*}{ Mean \pm SD } & Min-Max & \multirow{2}{*}{ Mean \pm SD } & Min-Max & \multirow{2}{*}{ Mean \pm SD } & Min-Max & & & \multirow{2}{*}{\multicolumn{2}{|c|}{$\mathrm{p}$ value }} \\
\hline & & (Median) & & (Median) & & (Median) & & & & \\
\hline Age (year) & $28.1 \pm 4.9$ & & $32.5 \pm 5.0$ & & $30.8 \pm 6.3$ & & $0.055^{\mathrm{A} / \mathrm{Tu}}$ & 0.05 & 0.54 & 0.313 \\
\hline Glucose (mg/dL) & $78.9 \pm 11.3$ & $\begin{array}{c}66-110 \\
(78)\end{array}$ & $92.7 \pm 25.1$ & $\begin{array}{c}66-197 \\
(87)\end{array}$ & $77.7 \pm 8.2$ & $\begin{array}{l}69-95 \\
(74.5)\end{array}$ & $0.0001^{\mathrm{A} / \mathrm{T}}$ & 0.001 & 0.01 & 0.698 \\
\hline G-UT (ng/mL) & $0.45 \pm 0.06$ & $\begin{array}{c}0.37-0.53 \\
(0.46)\end{array}$ & $0.6 \pm 0.3$ & $\begin{array}{c}0.22-1.26 \\
(0.56)\end{array}$ & $0.2 \pm 0.1$ & $\begin{array}{c}0.05-0.39 \\
(0.16)\end{array}$ & $\underset{\mathrm{m}}{0.0001^{\mathrm{A} / \mathrm{T}}}$ & 0.062 & 0.0001 & 0.0001 \\
\hline PP-UT (ng/mL) & $0.28 \pm 0.22$ & $\begin{array}{c}0.12-0.93 \\
(0.19)\end{array}$ & $0.5 \pm 0.4$ & $\begin{array}{c}0.01-1.27 \\
(0.42)\end{array}$ & $0.2 \pm 0.1$ & $\begin{array}{c}0.05-0.39 \\
(0.16)\end{array}$ & $0.005^{\mathrm{KW}}$ & $0.217^{\mathrm{m}}$ & $0.004^{\mathrm{m}}$ & $0.019^{\mathrm{m}}$ \\
\hline *p value & $0.036^{\mathrm{w}}$ & & $0.136^{\mathrm{p}}$ & & & & & & & \\
\hline
\end{tabular}

GDM: Gestational diabetes mellitus, SD: Standard deviation, A/Tu: ANOVA (Tukey), A/Tm: ANOVA (Tamhane's T2), KW:Kruskall-Wallis, m: Mann Whitney U, t: t test, p: gestational and postpartum UII (paired test), w: Gestational and Postpartum Urotensin II (Wilcoxon test), GUT: Gestational Urotensin II, PP-UT: Postpartum Urotensin II, * Pregnancy \& Post-partum

\section{$100 \mathrm{gr} \mathrm{OGTT}$}

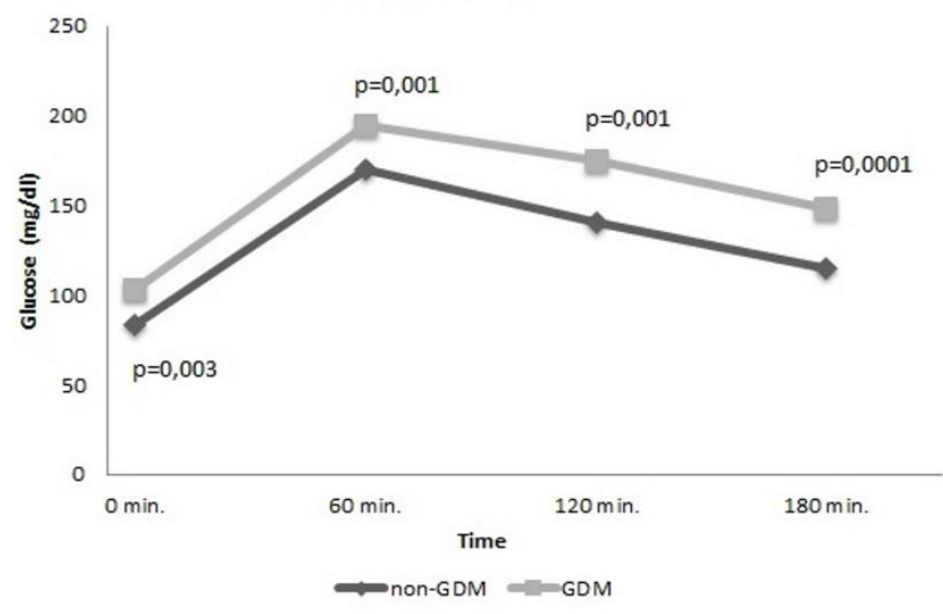

Figure 1: Gestational 3 hours 100 gram OGTT results of the pregnant subjects.

\section{5 gr OGTT}

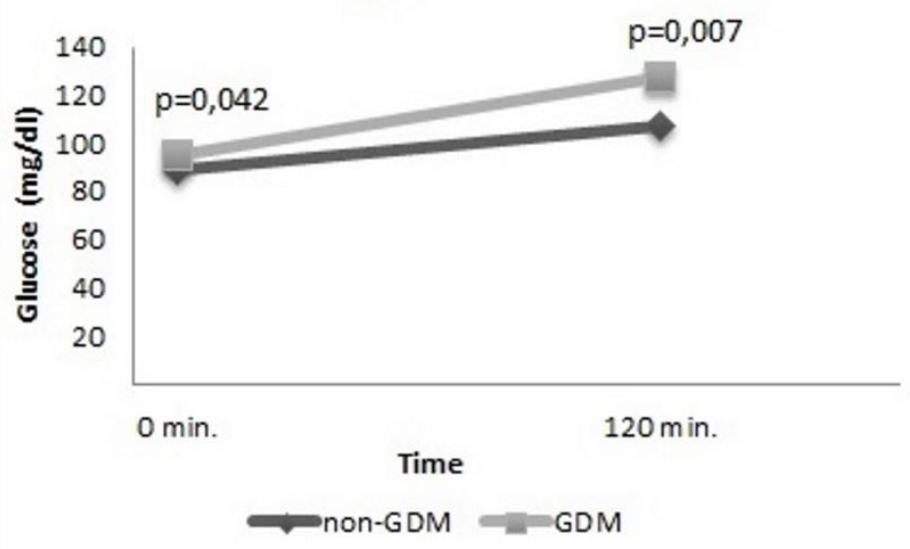

Figure 2: Postpartum 2 hours 75 gram OGTT results of the women.

There are studies about UII/UTR system in pregnancy and preeclampsia [12, 13]. Cowley et al. [14] has compared plasma UII levels between preeclampsia and normotensive pregnant women. Although mean arterial pressure levels were different between the two groups, plasma UII levels were not different. At delivery umbilical cord UII levels were higher than plasma UII levels in preeclampsia group [14]. In our pilot study, both gestational and postpartum plasma UII concentrations were significantly higher than the plasma UII concentrations of the healthy control group. Also both gestational and postpartum UII concentrations were higher in GDM than non-GDM patients but have not reached statistically significance (but it was close to significant in gestational period). But the important point to mention is that plasma UII levels of non-diabetic mothers were decreased significantly after delivery but not in GDM mothers (Table 1). The above Cowley's study findings indicate that the high plasma UII levels in GDM patients could not be attributed to the pregnancy alone. So it seems that UII, in addition to its vasoactive properties [15], it has also diabetogenic effects [6]. As we know, there are reports about the role of UII system in increasing genetic susceptibility to GDM [9].

Comparing of 100 gram OGTT in non-GDM pregnant women and GDM pregnant women reveals that plasma glucose increases in a same manner in both (but more prominent and/or pathological in GDM subject) (Figure 1). This similarity of postprandial plasma glucose increase manner in both may be due to high plasma UII levels of them (in relation to healthy controls) (Table 1). Unfortunately, we have not performed 100gr OGTT test in healthy controls to compare. As we know, UII/URS has structural similarity with somatostatin [16]. Maybe UII (like somatostatin) inhibits glucagon like peptide (GLP) secretion from the gut [17]. The supporting sign of this above thesis is the similarity between our postprandial plasma glucose response and non GLP-1 infused obese patients of Flint's study (which was higher than GLP-1 infused patients during postprandial period) [18]. Another supporting point of our thesis is recent evidence of success of metformin and glyburide in GDM management [19].

Another point to mention is that insulin sensitivity (as measured by HOMA-IR) was lower in GDM patients (in compare to non-GDM persons) at gestation and this sensitivity decreased more after delivery but not reached statistically significance. Insulin levels were not changed significantly as well ( $p \geq 0.05$ for all). Serum C-peptide levels were higher in GDM than non-GDM patients and even (opposite to non-GDM subjects) increased in GDM patients after delivery which made post-partum levels of them close to significant (Table 1). Whether this increase in c-peptide levels is a consequence or is a result needs to be investigated. C-peptide has a regulatory effect on B-cell function and insulin secretion. The glycated c-peptide has a less inhibitory effect than the non-glycated one [20].This may explain the increased insulin and HOMA-IR levels of GDM subjects after delivery in spite of higher postpartum C-peptide levels in GDM patients who also had high glucose and HbA1clevels (Table 2). This fact is also true for the effect of somatostatin and GLP-1 [20, 21].There was no significant difference in mean postpartum UII levels between non-GDM and 
Table 2: Gestational and post-partum laboratory results of the pregnant women.

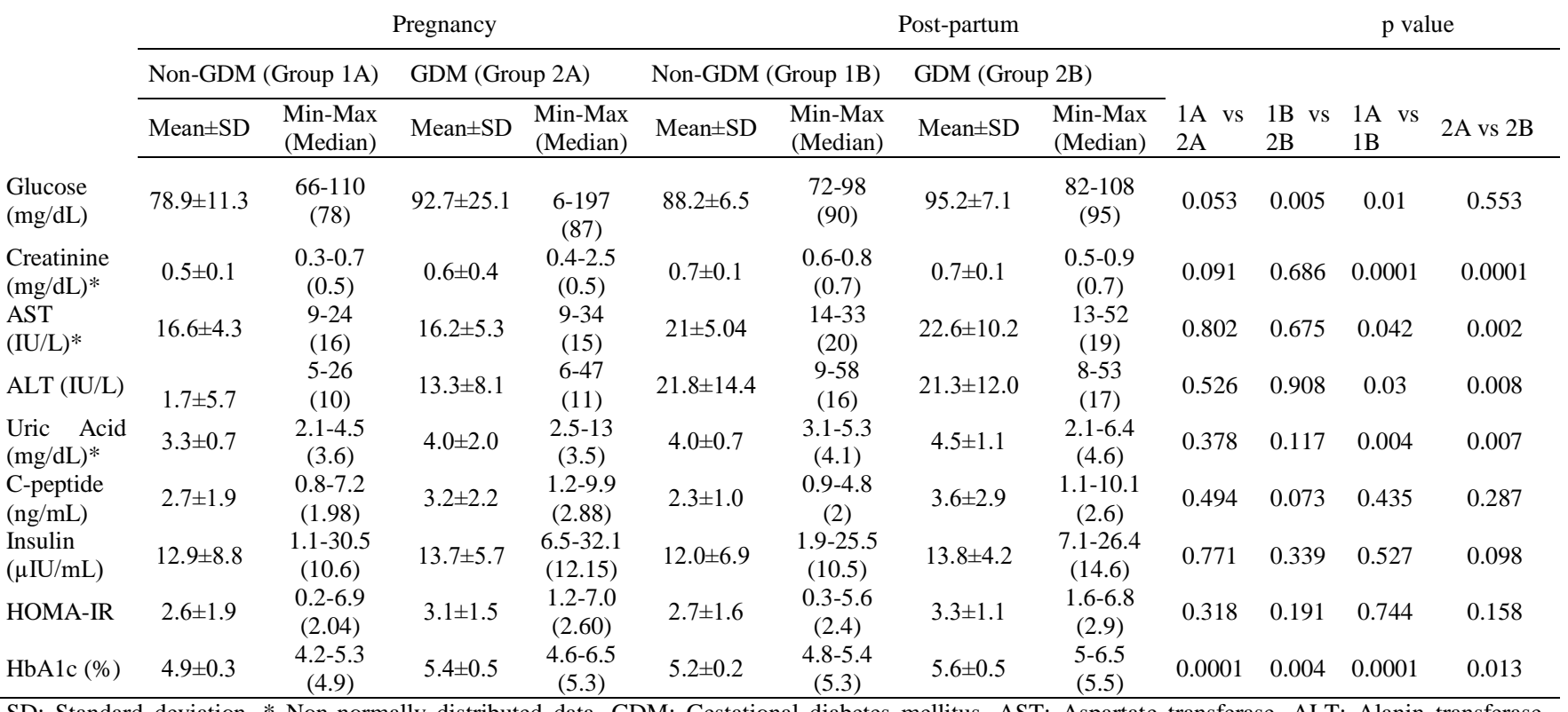

SD: Standard deviation. * Non-normally distributed data, GDM: Gestational diabetes mellitus, AST: Aspartate transferase, ALT: Alanin transferase, HOMA-IR: Homeostasis model assessment of insulin resistance, HbA1c: Glycosylated hemoglobin.

GDM patients. But their response to $75 \mathrm{gr}$ glucose loading test was in a similar manner (but was significantly higher in GDM group). Whether this is a different response due to the degree of glycosylation of UII between them needs to be further investigated (see figure 2).

In Cowley et al.'s [14] study, umbilical cord UII levels at delivery were higher than plasma UII levels in preeclampsia group. In our study, we have not determined umbilical cord UII levels or its expression to be evaluated. Also we have not determined insulin and /or c-peptide response in 100 gram OGTT tests to compare.

In conclusion, the finding of elevated gestational plasma UII levels in GDM patients which did not decrease significantly after delivery shows that UII /UTR system may have a role in the pathogenesis of GDM. Further detailed studies are needed in this field.

\section{References}

1. Watanabe T, Kanome T, Miyazaki A, Katagiri T. Human urotensin II as a link between hypertension and coronary artery disease. Hypertens Res 2006; 29: 375-87.

2. Dai HY, Guo XG, Ge ZM, Li ZH, Yu XJ, Tang MX, et al. Elevated expression of urotensin II and its receptor in diabetic cardiomyopathy. J Diabetes Complications 2008; 22: 137-43.

3. Ong KL, Wong LY, Cheung BM. The role of urotensin II in the metabolic syndrome. Peptides 2008; 29: 859-67.

4. Gruson D, Rousseau MF, Ketelslegers JM, Hermans MP. Raised plasma urotensin II in type 2 diabetes patients is associated with the metabolic syndrome phenotype. J Clin Hypertens (Greenwich) 2010; 12: 653-60.

5. Tian L, Li C, Qi J, Fu P, Yu X, Li X, et al. Diabetes-induced up regulation of urotensin II and its receptor plays an important role in TGF-beta1-mediated renal fibrosis and dysfunction. Am J Physiol Endocrinol Metab 2008; 295: E1234-42.

6. Marco J, Egido EM, Hernandez R, Silvestre RA. Evidence for endogenous urotensin-II as an inhibitor of insulin secretion. Study in the perfused rat pancreas. Peptides 2008; 29: 852-8.

7. Cheung K, Wong S. Gestational diabetes mellitus update and review of literature. Reproductive Sys Sexual Disord 2012; S: 2.
8. Al-Noaemi MC, Shalayel MHF. Pathophysiology of Gestational Diabetes Mellitus: The Past, the Present and the Future. Gestational Diabetes 2011; 91.

9. Tan YJ, Fan ZT, Yang HX. [Role of urotensin II gene in the genetic susceptibility to gestational diabetes mellitus in northern Chinese women]. Zhonghua Fu Chan Ke Za Zhi 2006; 41: 732-5.

10. Metzger BE, Gabbe SG, Persson B, Buchanan TA, Catalano PA, Damm $\mathrm{P}$, et al. International association of diabetes and pregnancy study groups recommendations on the diagnosis and classification of hyperglycemia in pregnancy. Diabetes Care 2010; 33: 676-82.

11. Hursitoglu M, Tukek T, Cikrikcioglu MA, Kara O, Kazancioglu R, Ozkan O, et al. Urotensin II levels in patients with chronic kidney disease and kidney transplants. Ups J Med Sci 2012; 117: 22-7.

12. Balat O, Aksoy F, Kutlar I, Ugur MG, Ugur MG, Iyikosker H, Balat A, et al. Increased plasma levels of Urotensin-II in preeclampsiaeclampsia: a new mediator in pathogenesis? Eur J Obstet Gynecol Reprod Biol 2005; 120: 33-8.

13. Na S, Shim JY, Jung BK, Won HS, Lee PR, Kim A. Urotensin-II $143 \mathrm{G} / \mathrm{A}$ polymorphism is not associated with the risk of preeclampsia in Korean women. Am J Reprod Immunol 2011; 66: 423-7.

14. Cowley E, Thompson JP, Sharpe P. Effects of pre-eclampsia on maternal plasma, cerebrospinal fluid, and umbilical cord urotensin II concentrations: a pilot study. Br J Anaesth 2005; 95: 495-9.

15. Totsune K, Takahashi K, Arihara Z, Sone M, Ito S, Murakami O. Increased plasma urotensin II levels in patients with diabetes mellitus. Clin Sci (London) 2003; 104: 1-5.

16. Silvestre RA, Egido EM, Hernandez R, Leprince J, Chatenet D, Tollemer $\mathrm{H}$, et al. Urotensin-II is present in pancreatic extracts and inhibits insulin release in the perfused rat pancreas. Eur J Endocrinol 2004; 151: 803-9.

17. Hansen L, Hartmann B, Bisgaard T, Mineo H, Jørgensen PN, Holst JJ. Somatostatin restrains the secretion of glucagon-like peptide-1 and -2 from isolated perfused porcine ileum. Am J Physiol Endocrinol Metab 2000; 278: E1010-8.

18. Flint A, Raben A, Ersboll AK, Holst JJ, Astrup A. The effect of physiological levels of glucagon-like peptide- 1 on appetite, gastric emptying, energy and substrate metabolism in obesity. Int $\mathrm{J}$ Obes Relat Metab Disord 2001; 25: 781-92.

19. Kalra B, Gupta Y, Singla R, Kalra S. Use of oral anti-diabetic agents in pregnancy: a pragmatic approach. N Am J Med Sci 2015; 7: 6-12.

20. NG, Ming Tak. Effects of pro insulin C-peptide and other islet peptides on beta-cell function and insulin secretion. 2011. PhD Thesis. University of Ulster. http://ethos.bl.uk/OrderDetails.do?uin=uk.bl.ethos.554231. 
21. O'Harte FP, Abdel-Wahab YH, Conlon JM, Flat PR. Glycation of glucagon-like peptide-1(7-36) amide: characterization and impaired action on rat insulin secreting cells. Diabetologia 1998; 41: 1187-93. 